\title{
Hydrogeochemical evaluation of groundwater in Ibillo, Akoko-Edo Local Government area, Edo State Nigeria
}

\author{
Olaniran Emmanuel, Aluko ${ }^{1,}$, Williams Ogbevire, Emofurieta ${ }^{2}$ \\ ${ }^{1}$ African Regional Centre for Space Science and Technology Education-English, Ile-Ife, Osun State, Nigeria \\ ${ }^{2}$ Department of Geology, University of Benin, Benin City, Edo State, Nigeria
}

\section{Email address:}

alukoolaniran@yahoo.com (Aluko O. E.)

\section{To cite this article:}

Olaniran Emmanuel, Aluko, Williams Ogbevire, Emofurieta. Hydrogeochemical Evaluation of Groundwater in Ibillo, Akoko-Edo Local Government Area, Edo State Nigeria. International Journal of Science, Technology and Society. Vol. 2, No. 5, 2014, pp. 103-108. doi: 10.11648/j.ijsts.20140205.12

\begin{abstract}
Ibillo town, located in Edo State, Southsouth Nigeria, is an important agricultural and commercial center. In recent years, rapid development has created an increase in demand for groundwater and frequently facing water scarcity as well as quality problems. Hydrogeochemical evaluations of ionic abundance in groundwater systems in Ibillo was conducted by collecting a total of 50 groundwater samples for Dry and Rainy seasons, and were subjected to analysis for chemical and microbial characteristics. The study reveal that $\mathrm{pH}$ in the area is slightly acidic to alkaline ranging from 5.9 to 8.1. The electrical conductivity and total dissolved solids (TDS) values was noted higher during the rainy season. The abundance of major ions in the groundwater is in the order of $\mathrm{K}>\mathrm{Na}>\mathrm{Ca}>\mathrm{Mg}=\mathrm{Cl}>\mathrm{HCO}_{3}>\mathrm{SO}_{4}>\mathrm{NO}_{3}$. Total hardness, $\mathrm{Na}, \mathrm{Fe}, \mathrm{Mn}, \mathrm{Cu}, \mathrm{Cl}$, $\mathrm{HCO}_{3}, \mathrm{SO}_{4}, \mathrm{NO}_{3}, \mathrm{Fl}, \mathrm{NO}_{2}$ and $\mathrm{PO}_{4}$ do not exceed the WHO permissible limit during both seasons. Ca and $\mathrm{Mg}$ in majority of the groundwater samples are within the permissible limit with few exceptions irrespective of seasons. $\mathrm{K}$, $\mathrm{Pb}$ and $\mathrm{Ni}$ exceed the permissible limit during both seasons while $\mathrm{Cr}, \mathrm{Zn}$ and $\mathrm{Ba}$ concentrations partially conform to the WHO limits irrespective of seasons. Most of the groundwater samples examined have high E. coli and total bacterial counts. A comparison of the results with relevant standards show that the water require various form of treatment to bring the microbial contents to standards required for domestic and industrial uses respectively. The type of water that predominates in the study area is $\mathrm{Na}-\mathrm{K}-\mathrm{Cl}$ type and mixed type. Besides, suitability of water for irrigation is evaluated based on sodium adsorption ratio, sodium percent and salinity hazard. It is observed that majority of samples irrespective of seasons fall in "excellent-good" zone indicating water is fit for irrigation purposes. The groundwater in this study area can be said to be partially good for industrial sectors but it require a little treatment for it to be completely suitable for industry.
\end{abstract}

Keywords: Groundwater Quality, Ionic Ratio, Ibillo, Hydrogeochemical Evaluation

\section{Introduction}

Water is the most common substance on earth. It covers more than $70 \%$ of the earth's surface and free water (i.e that not bound up in minerals) comprises only about $0.02 \%$ of the Earth's mass, but without it life could not exist. It fills the oceans, rivers, streams and lakes (surface water). It is in the ground (groundwater) and in the air we breathe.

Groundwater and surface water are important resources for abstraction for beneficial use and irrigation purposes and also important features of the natural environment. Groundwater has a strong interaction with many surface water features such as rivers, wetlands and with the wider environment, which leads to environmental problems and may in some cases offer a medium for environmental solution. Despite the vital importance of groundwater and surface water to man, his animal and plant, it is subject to pollution. Water acquires its salinity and bacteriological composition partly as it passes through the atmosphere by dissolving air-borne particulates and water-soluble gases, and also incorporating air-borne microbes [1 and 10]. Its quality may further be degraded as it infiltrates the soil, causing leaching and weathering of the geological medium, which results in the dissolution or precipitation of some mineral constituents in the soil, and enhances groundwater salinity [4, 5, 9 and 10].

Over the years, emphasis in water resource assessment in developing and industrialized countries has shifted to its 
quality. In general, raw water quality is influenced by both natural and human use factors. Important natural factors include wildlife, climate, topography, geology and vegetation. Human use factors include point sources (e.g municipal, and industrial wastewater discharges) and non-point sources (e.g. urban and agricultural runoff, including agrochemicals, livestock or recreational use) [2 and 3]. For example, discharges of municipal wastewater can be a major source of pathogens; urban runoff and livestock can contribute substantial microbial load; body contact recreation can be a source of faecal contamination; and agricultural runoff can lead to increased challenges to treatment [7 and 11].

As a consequence, changes in groundwater levels or quality can have detrimental environmental impacts. The threat to human population may occur through drinking the water from contaminated or polluted wells or rivers. Even as the trend of population increases and industries develop, greater and industrial quantities of water are being required all over the globe with respect to Man's use for life sustenance [14, 17 and 18].

In a bid to promoting healthy living amongst the inhabitants of any defined geological region, an adequate supply of clean wholesome water is highly essential. Good quality water better referred to as potable water is the one that is safe to drink, pleasant to the taste and useable for domestic purposes [14, 15 and 16].

However, if groundwater and surface water are to continue to play an important role in the development of the world's water resources potential, then it will have to be protected from the increasing threat to subsurface and surface pollutants.

\section{Description of the Study Area}

Ibillo lies between latitude $7^{\circ} 25^{1} \mathrm{~N}$ and $7^{\circ} 30^{1} \mathrm{~N}$ and longitudes $6^{\mathrm{o}} 03^{1} \mathrm{E}$ and $6^{\mathrm{o}} 06^{1} \mathrm{E}$. It is one of the major towns in Akoko-Edo Local Government Area of Edo State, Nigeria. It covers an area of $121 \mathrm{~km}^{2}$ and forms the upper left quadrant of 1:50000 GSN Sheet 266 (Auchi N.W) [8].

The area under study relatively has a high relief. The highest area is at the North Western portion with an average height of about $459 \mathrm{~m}$ above sea level, while the relatively lower portions occur at the Southern and Central portion with an average height of about $306 \mathrm{~m}$ above sea level. The relief of the area consists of isolated hills and inselbergs. The elevations of these vary from few meters to few kilometers. The highlands are however separated by sometimes extensive lowlands. The valley has a general "V" to " $U$ " shape.

Ibillo lies within the transition zone of the tropical and equatorial climates. There are no marked seasonal differences except in rainfall. The rainy season commences in April and persist till September or October and the dry season from November to March.

The average daily temperature is about $27^{\circ} \mathrm{C}$, the average daily range of approximately $7^{\circ} \mathrm{C}$ between the maximum of $30^{\circ} \mathrm{C}$ and an average minimum of $23^{\circ} \mathrm{C}$. The temperature of this area is controlled by precipitation and cloud.

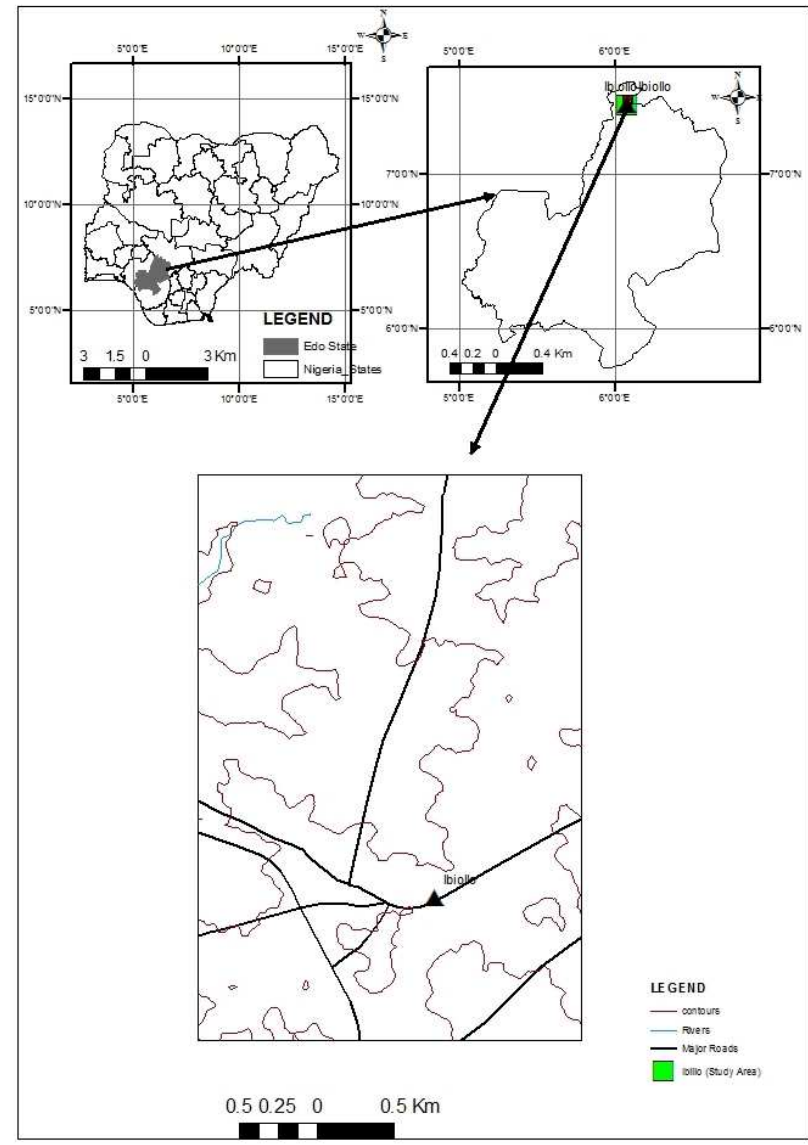

Fig. 1. Location map of the study area

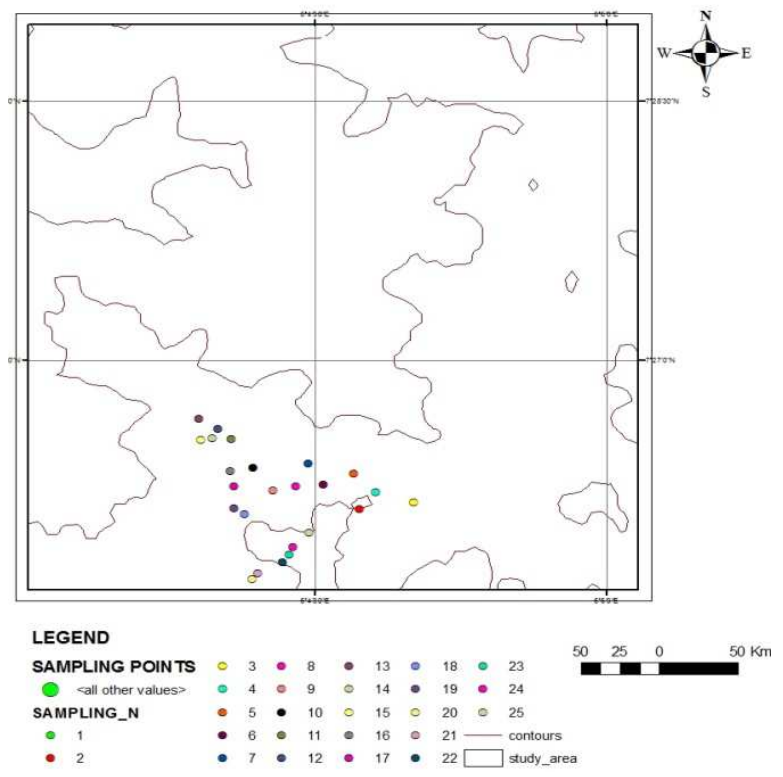

Fig. 2. Map of the study area showing the sampling points

The vegetation pattern in this area is the guinea savanna, characterized by presence of tall grasses, tall trees with broad leaves. These trees are scattered and sparse on the highlands and are moderately dense on the lowlands. In the 
dry season, these trees are deciduous that is they shed their leaves. The vegetation pattern was observed to be geologic, topographic and drainage controlled with especially dense vegetation occurring along the streams channels.

The drainage pattern of this area is mostly dendritic and drained majorly by River Ukpessi which flows westwards. The river is controlled by topography. Most of the streams are seasonal and flow in different directions.

\section{Methodology}

Twenty five groundwater samples were collected in one liter polythene bottles during Dry and Rainy season respectively to broadly cover the seasonal variations. A total of 50 samples were collected for two seasons. Great care was taken for the spatial distribution of the samples. The selected wells are used for domestic and agricultural purposes.

The samples were filtered using $0.45 \mu$ Millipore filters and analyzed for chemical constituents by using standard procedures [6]. The $\mathrm{pH}$ and electrical conductivity (EC) were measured using $\mathrm{pH}$ and electrical conductivity meters. TDS and TSS were determined by gravimetric method. Calcium (Ca) and magnesium $(\mathrm{Mg})$ were determined titrimetrically using standard EDTA. Chloride was determined by standard $\mathrm{AgNO}_{3}$ titration. Bicarbonate $\left(\mathrm{HCO}_{3}\right)$ was determined by titration with $\mathrm{HCl}$. Sodium $(\mathrm{Na})$ and potassium $(\mathrm{K})$ were measured by flame photometry, sulphate $\left(\mathrm{SO}_{4}\right)$ by spectrophotometer turbidimetry.

Heavy metals were analyzed using Atomic absorption spectrometric methods [6]. The coliform counts were carried out by means of the standard plate count technique using MacConkey agar [6 and 12]

\section{Results and Discussion}

Table 1. Statistical parameters for groundwater during Dry and Rainy seasons

\begin{tabular}{|c|c|c|c|c|c|c|c|c|}
\hline \multirow{2}{*}{ Parameters } & \multicolumn{2}{|c|}{ Minimum } & \multicolumn{2}{|c|}{ Maximum } & \multicolumn{2}{|l|}{ Mean } & \multicolumn{2}{|c|}{ Std Deviation } \\
\hline & DRY & RAINY & DRY & RAINY & DRY & RAINY & DRY & RAINY \\
\hline $\mathrm{pH}$ & 5.90 & 6.00 & 8.10 & 7.60 & 7.07 & 6.95 & 0.59 & 0.40 \\
\hline Cond. $\mu \mathrm{S} / \mathrm{cm}$ & 20.00 & 40.00 & 910.00 & 1380.00 & 424.40 & 541.60 & 241.25 & 358.50 \\
\hline TDS mg/l & 13.00 & 26.80 & 610.00 & 925.00 & 267.84 & 362.02 & 166.50 & 239.97 \\
\hline TSS mg/l & 5.70 & 13.20 & 176.00 & 489.00 & 81.73 & 188.66 & 46.05 & 133.19 \\
\hline THard mg/l & 62.00 & 50.00 & 384.00 & 390.00 & 202.84 & 212.43 & 94.55 & 99.47 \\
\hline $\mathrm{Ca}^{2+} \mathrm{mg} / \mathrm{l}$ & 6.40 & 6.40 & 93.00 & 103.00 & 48.11 & 51.68 & 25.16 & 26.59 \\
\hline $\mathrm{Mg}^{2+} \mathrm{mg} / \mathrm{l}$ & 4.20 & 1.50 & 41.70 & 42.90 & 19.61 & 20.39 & 11.14 & 10.10 \\
\hline $\mathrm{K} \mathrm{mg} / \mathrm{l}$ & 36.90 & 55.90 & 131.10 & 130.30 & 84.20 & 93.90 & 22.98 & 20.54 \\
\hline $\mathrm{Cl}^{-} \mathrm{mg} / \mathrm{l}$ & 20.70 & 20.70 & 228.00 & 224.00 & 92.87 & 95.24 & 65.49 & 57.80 \\
\hline $\mathrm{HCO}_{3} \mathrm{mg} / \mathrm{l}$ & 4.00 & 10.00 & 60.00 & 200.00 & 24.21 & 85.62 & 15.97 & 57.11 \\
\hline $\mathrm{SO}_{4} \mathrm{mg} / \mathrm{l}$ & 8.00 & 4.00 & 70.00 & 104.00 & 34.40 & 44.40 & 18.77 & 29.35 \\
\hline $\mathrm{Na} \mathrm{mg/l}$ & 14.00 & 13.50 & 148.00 & 145.60 & 60.40 & 59.10 & 42.40 & 37.45 \\
\hline E. coli cfu $/ 100 \mathrm{ml}$ & 0 & & 0 & & 6 & & 8 & \\
\hline TBC cfu/ $0.1 \mathrm{ml}$ & 2 & & 3 & & 44 & & 48 & \\
\hline
\end{tabular}

\subsection{Irrigation Purposes}

The suitability of water for irrigation purposes depends upon its mineral constituents. The general criteria for judging the quality are: (i) Total salt concentration as measured by electrical conductivity (EC) (ii) Relative proportion of sodium to other principal cations as expressed by SAR, (iii) Bicarbonate $\left(\mathrm{HCO}_{3}\right)$ and (iv)Boron.

For this study, the \% $\mathrm{Na}$ and SAR are used to classify the water for irrigation purpose. The sodium in irrigation waters is usually denoted as per cent sodium and can be determined using the following formula.

$$
\% \mathrm{Na}=\left(\mathrm{Na}^{+}\right) \times 100 /\left(\mathrm{Ca}^{2+}+\mathrm{Mg}^{2+}+\mathrm{Na}^{+1}+\mathrm{K}^{+1}\right)
$$

where the quantities of $\mathrm{Ca}^{2+}, \mathrm{Mg}^{2+}, \mathrm{Na}^{+}$and $\mathrm{K}^{+}$are expressed in milliequivalents per litre (epm).

The classification of groundwater samples with respect to per cent sodium is shown in Table 2. It is observed that majority of samples irrespective of seasons fall in "excellent-good" zone indicating water is fit for irrigation purposes. Few representation of "medium" water was also noted.
In the past, the sodium hazard has been expressed as per cent sodium of total cations. A better measure of the sodium hazard for irrigation is the SAR which is used to express reactions with the soil. This index quantifies the proportion of sodium $(\mathrm{Na})$ to calcium $(\mathrm{Ca})$ and magnesium $(\mathrm{Mg})$ ions in a sample.

$\mathrm{SAR}$ is computed as

$$
\mathrm{SAR}=\frac{\mathrm{Na}^{+}}{\left\{\frac{\mathrm{Ca}^{2-}+\mathrm{Mg}^{2+}}{2}\right\}^{1 / 2}}
$$

where all ionic concentrations are expressed in epm.

The classification of groundwater samples from the study area with respect to SAR is represented in Table 2. During dry and rainy season, the SAR value of all the samples are found to be less than 10, and are classified as excellent for irrigation.

When the concentration of sodium ion is high in irrigation water, $\mathrm{Na}$ tends to be absorbed by clay particles, displacing magnesium and calcium ions. This exchange process of sodium in water for $\mathrm{Ca}$ and $\mathrm{Mg}$ in soil reduces the permeability and eventually results in soil with poor 
internal drainage.

Table 2. Classification of groundwater based on drinking and agricultural utilities

\begin{tabular}{|c|c|c|c|}
\hline TDS mg/l & $\begin{array}{l}\text { Water } \\
\text { Classification }\end{array}$ & $\begin{array}{l}\text { Groundwater } \\
\text { Dry }(\mathbf{n}=\mathbf{2 5})\end{array}$ & $\begin{array}{l}\text { Seasons } \\
\text { Rainy(n=25) }\end{array}$ \\
\hline$<1000$ & Fresh water & 25 & 25 \\
\hline $1000-10000$ & Brackish water & Nil & Nil \\
\hline $10000-100000$ & Saline water & Nil & Nil \\
\hline$>100000$ & Brine water & Nil & Nil \\
\hline $\begin{array}{l}\text { Total Hardnes } \\
\text { as } \mathrm{CaCO}_{3} \mathrm{mg} / \mathrm{l}\end{array}$ & $\begin{array}{l}\text { Water } \\
\text { Classification }\end{array}$ & $\begin{array}{l}\text { Groundwater } \\
\text { Dry }(n=25)\end{array}$ & $\begin{array}{l}\text { Seasons } \\
\text { Rainy }(\mathrm{n}=\mathbf{2 5})\end{array}$ \\
\hline$<50$ & Soft water & Nil & Nil \\
\hline $50-150$ & $\begin{array}{l}\text { Moderately } \\
\text { Hard }\end{array}$ & 8 & 7 \\
\hline $150-300$ & Hard & 14 & 13 \\
\hline$>300$ & Very Hard & 3 & 5 \\
\hline $\mathrm{EC}(\mu \mathrm{S} / \mathrm{cm})$ & $\begin{array}{l}\text { Water } \\
\text { Classification }\end{array}$ & $\begin{array}{l}\text { Groundwater } \\
\text { Dry }(\mathbf{n}=\mathbf{2 5})\end{array}$ & $\begin{array}{l}\text { Seasons } \\
\text { Rainy }(n=25)\end{array}$ \\
\hline$<250$ & Excellent & 7 & 7 \\
\hline $250-750$ & Good & 15 & 13 \\
\hline $750-2000$ & ermissible & 3 & 5 \\
\hline $2000-3000$ & Ooubtful & Nil & Nil \\
\hline$\% \mathrm{Na}$ & $\begin{array}{l}\text { later } \\
\text { lassification }\end{array}$ & $\begin{array}{l}\text { Groundwater } \\
\text { Dry }(\mathrm{n}=\mathbf{2 5})\end{array}$ & $\begin{array}{l}\text { Seasons } \\
\text { Rainy }(n=25)\end{array}$ \\
\hline$<20$ & xcellent & 8 & 9 \\
\hline $20-40$ & ood & 14 & 14 \\
\hline $40-60$ & ermissible & 3 & Nil \\
\hline $\begin{array}{l}60-80 \\
>80 \\
\text { Unsuitable } \\
\end{array}$ & oubtful & $\begin{array}{l}\text { Nil } \\
\text { Nil }\end{array}$ & $\begin{array}{l}\text { Nil } \\
\text { Nil }\end{array}$ \\
\hline SAR & $\begin{array}{l}\text { ater } \\
\text { assification }\end{array}$ & $\begin{array}{l}\text { Groundwater } \\
\text { Dry }(n=25)\end{array}$ & $\begin{array}{l}\text { Seasons } \\
\text { Rainy }(n=25)\end{array}$ \\
\hline$<10$ & cellent & 25 & 25 \\
\hline $10-18$ & od & Nil & Nil \\
\hline $18-26$ & ubtful & Nil & Nil \\
\hline$>26$ & isuitable & Nil & Nil \\
\hline
\end{tabular}

\subsection{Industrial Purpose}

The quality requirements for industrial water supplies range widely and almost every industrial unit has its own standards. Water used by industry can be classified as cooling, boiler and process waters. Industries frequently suffer from incrustation and corrosion, which are chemical reactions caused by poor quality of waters. Incrustation involves deposition of undesirable material, whereas corrosion is a chemical action on metals, resulting in the metal being eaten away. In this study, the following water quality criteria have been adopted [16] for defining the incrusting and corrosive properties of waters: waters having more than $300 \mathrm{mg} / 1$ of Total Hardness or $100 \mathrm{mg} / \mathrm{l}$ of $\mathrm{SO}_{4}$ or $400 \mathrm{mg} / \mathrm{l}$ of $\mathrm{HCO}_{3}$ or $40 \mathrm{mg} / 1$ of $\mathrm{Si}$, may cause incrustation and water with $\mathrm{pH}$ less than 7 or TDS more than $1000 \mathrm{mg} / \mathrm{l}$ or $\mathrm{Cl}$ more than $500 \mathrm{mg} / \mathrm{l}$ may cause corrosion.

Total Hardness more than $300 \mathrm{mg} / \mathrm{l}$ is represented in about $12 \%$ (dry season) and $20 \%$ (rainy season) of the groundwater samples in the study area (Table 2), which may cause incrustation.

The $\mathrm{pH}$ of the groundwater is in the range of 5.9-8.1. Of these, $40 \%$ (dry season) and $44 \%$ (rainy season) fall below the criteria for defining the corrosive properties of water $(\mathrm{pH}<7)$ and as a result may cause corrosion. The groundwater in this study area can be said to be partially good for industrial sectors but it require a little treatment for it to be completely suitable for industry.

\subsection{Hydrogeochemical Facies}

The evolution of hydrochemical parameters of groundwater can be understood by plotting the concentration of major cations and anions in the Piper, 1944 diagram (Fig. 3 and 4) [13]. It helps in recognizing various hydrogeochemical types in a groundwater environment [3 and 13].

The plot shows that most of the groundwater samples analyzed during both seasons falls in the field of Na-K-Cl and mixed type. During the dry season, $84 \%$ of the ground water samples are of chloride type and $16 \%$ are of mixed type. In the cations facies, the well water samples are about $68 \%$ sodium/potassium type and $32 \%$ of mixed. During the rainy season, $88 \%$ of the ground water samples are of chloride type, $12 \%$ are of mixed type. In the cations facies, the groundwater samples are about $80 \%$ sodium/potassium type and $20 \%$ of mixed type and the stream samples are $100 \%$ sodium/potassium type. From the plot, it is observed that alkali ( $\mathrm{Na}$ and $\mathrm{K})$ exceeds alkaline earth $(\mathrm{Ca}$ and $\mathrm{Mg})$ and strong acids exceed weak acids; in general water chemistry of the study area is dominated by alkali and strong acids.

There is no significant change in the hydro-chemical facies noticed during the study period (dry and rainy), which indicates that most of the major ions are natural in origin. The reason is groundwater passing through igneous rocks dissolves only small quantities of mineral matters because of the relative insolubility of the rock composition.

The plot is as shown below:

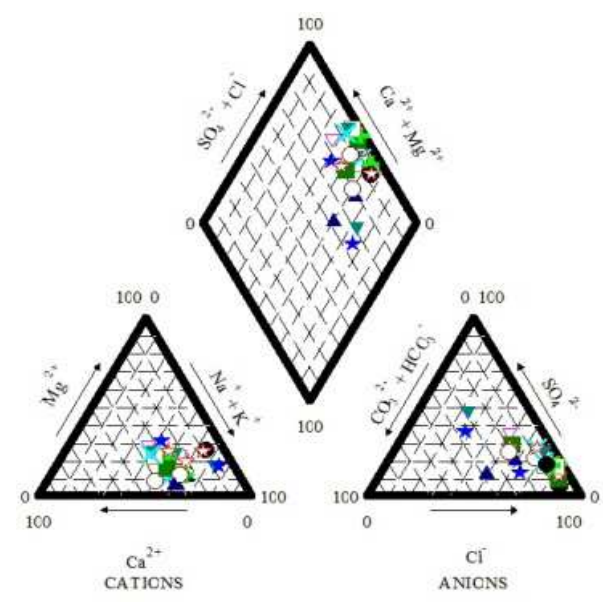

Fig. 3. Piper trilinear diagram of the studied groundwater samples for Dry season. 


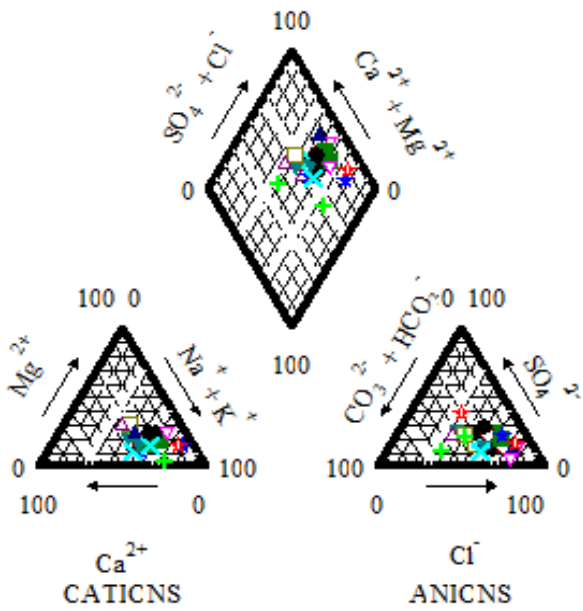

Fig. 4. Piper trilinear diagram of the studied groundwater samples for Rainy season.

\section{Conclusions}

The following conclusions can be drawn based on the results of the laboratory analysis and various statistical analysis carried out on the results.

- The groundwater in the study area is odourless and contains free carbon (iv) oxide. The alkalinity of the water is entirely due to bicarbonate ions.

- The prevailing hydrochemical processes operating here is simple dissolution, mixing, weathering of carbonate minerals and of silicate, ion exchange, and surface water interaction.

- The type of water that predominates in the study area is Na-K-Cl type during both dry and rainy seasons of the year 2009, based on hydrochemical facies. $\mathrm{Na}, \mathrm{K}, \mathrm{Ca}$, and $\mathrm{Mg}$ are the most abundant dissolved cations in the water while $\mathrm{Fe}, \mathrm{Mn}, \mathrm{Cu}, \mathrm{Pb}$, $\mathrm{Zn}, \mathrm{Cr}, \mathrm{Ba}$ and Ni have little or low concentrations, but of all the heavy metals, it is $\mathrm{Pb}$ and $\mathrm{Ni}$ concentrations that exceeded the WHO recommended limits while $\mathrm{Cr}, \mathrm{Zn}$ and $\mathrm{Ba}$ concentrations partially conform to the WHO limits.

- Highly populated areas have groundwater with high concentration of dissolved ions and the converse for areas of low population. One can therefore conclude that the groundwater chemistry has been more influenced by human activities than the bedrock geology.

- Even though the physical and chemical composition of the water masses within Ibillo and environs fall within the limits of acceptable standard for irrigation but may require some treatment for it to be used for domestic purposes and in the industry.

- $\quad$ All the dissolved anions in the water samples are generally below the recommended maximum limits by WHO except for phosphate which partially conform to the WHO limits.
- The water samples also showed high bacterial load, which primarily originated from the infiltration of leachates from refuse dumps and septic tanks that are sited close to the wells and streams and can constitute a health risk on ingestion.

\section{References}

[1] Adekunle I. M; Adetunji M. T; Gbadebo A. M. and Banjoko O. B. (2007). Assessment of Groundwater Quality in a Typical Rural Settlement in Southwest Nigeria. Int. J. Environ. Res. Public Health. 4(4)308

[2] Ademoroti, C.M.A. (1996). Environmental Chemistry and toxicology. Foludex Press Limited, Ibadan. First Edition, Pp. $171-183$

[3] Ahmad, Z. A., Mohd, H. A. and Kyoung-Woong K. (2007).Hydrogeochemistry of Groundwater in Manukan Island, Saban Malaysia. The Malaysian Journal of Analytical Sciences, Vol 11, No 2: 407 - 413

[4] Ako, B.D; Adepelumi, A. and Ajayi, I. T. (2001): Groundwater contamination in basement-complex area of Ile-Ife, southwestern Nigeria: A case study using the electrical-resistivity of geographical method. Hydrogeology Journal. 9(6), 611 -622.

[5] Akujieze C.N and Oteze G.E (2006). Groundwater Quality of Benin City Urban aquifer of the Pleistocene - Oligocene Benin Formation, Nigeria. Afr. Sci. 7(2):69-85.

[6] American Public Health Association (2005). Standard methods for the Examination of water and wastewater, $19^{\text {th }}$ edition, Washington D.C

[7] Efe, S.I; Ogban, F.E; Horsfall, M Jr.; and Akporhnor, E.E (2005). Seasonal variations of physico-chemical characteristics in water resources quality in Western Niger Delta region, Nigeria, J. Applies Sci. Environ. Mgt. 9(1),191-195

[8] NGSA (2006). Geological Map of Nigeria, Nigeria Geological Survey Agency, Abuja.

[9] Nwankwoala, H.O and Udom, G.J (2011a). Hydrochemical Facies and Ionic Ratios of Groundwater in Port Harcourt, Southern Nigeria. Research Journal of Chemical Sciences, Vol.1(3): $87-101$.

[10] Olobaniyi S.B and Efe S.I (2007). Comparative assessment of rainwater and groundwater quality in an oil producing area of Nigeria: Environmental and health implications. J. Environ. Health Res. 6(2):111-118.

[11] Olobaniyi, S.O.B and Owoyemi, F.B (2002). Quality of Groundwater in the Deltaic Plain sands aquifer of Warri and Environs, Delta State, Nigeria. Journal of the Nigerian Association of Hydrogeologists (NAH), Vol 15,

[12] Olutiola, P. O; Famurewa, O. and Sonntag, H. G. (2000).An Introduction to General Microbiology. A practical Approach. Bolabay Publications. Pp. 93 - 111.

[13] Piper,A.M (1944).A Graphical Procedure in the Geochemical Interpretation of Water Analyses. American Geophysical Union Transactions, Vol.25:914-923 
[14] Standard Organization of Nigeria (2007). Nigerian Standards for Drinking Water Quality. Nigerian Industrial Standards, NIS 554, Standards Organization of Nigeria.pp30

[15] Steel, E. W. and Torence, P. R. (1979). McGhee Water Supply and Sewage, $5^{\text {th }}$ Edition, Pp. $190-192$.

[16] Subba Rao, N., (2006). Seasonal variation of groundwater quality in part of Guntur district, Andhra Pradesh, India.Environmental Geology, 44(5), 579- 586.
[17] United States Environmental Protection Agency (2002) National Recommended water Quality criteria. Washington DC, US. Environmental Protection Agency Office of Water.

[18] World Health Organization (WHO) (2006). Guidelines for drinking water quality criteria, $2^{\text {nd }} \mathrm{Ed}, \mathrm{Vol} .2, \mathrm{pp} 281-308$, World Health Organization, Geneva. 